\title{
Troika of Trade Openness, Poverty and Income Inequality: Empirical Evidence from Lower and Middle Income Countries
}

\author{
Rashid Sattar ${ }^{\text {a }}$, Rana Ejaz Ali Khan ${ }^{\text {b }}$ \\ ${ }^{a}$ Assistant Professor, Department of Economics, The Islamia University of Bahawalpur, Pakistan \\ E-mail: rashid.sattar@iub.edu.pk \\ ${ }^{\mathrm{b}}$ Professor and Chairman, Department of Economics, The Islamia University of Bahawalpur, Pakistan \\ E-mail: ranaejazalikhan@yahoo.com
}

\begin{tabular}{l}
\hline ARTICLE DETAILS \\
\hline History: \\
Accepted 10 May 2021 \\
Available Online June 2021 \\
\\
Keywords: \\
Trade Openness, Poverty, Income \\
Inequality, Financial \\
Development \\
\hline JEL Classification: \\
P33, I32, O15 \\
\hline
\end{tabular}

DOI: $10.47067 /$ reads.v7i2.355

\begin{abstract}
The current study investigates the relationship among trade openness, poverty and income inequality in the developing economies classified as lower and middle income countries. Kao and Fisher cointegration tests are employed to see the long-run equilibrium relationship among the variables. Panel cointegration regression is employed to calculate the magnitude of variables through FMOLS and DOLS techniques. The results demonstrate that interaction of these three variables differ for income groups of countries, however, trade openness and poverty increase income inequality in both groups. Similarly, income inequality decreases trade openness in both lower income and middle income groups of the economies. Trade openness increases poverty in lower income countries only. Poverty increases income inequality in lower income countries but in middle income countries it decreases trade openness. In the control variables the financial development has shown encouraging effect on trade openness in lower and middle income countries. GDP growth has shown positive impact on income inequality in lower income countries but negative impact in middle income countries. As trade openness has discoursing effect so the economies should carefully deal with the implications through proper policy framework.
\end{abstract}

(C) 2021 The authors. Published by SPCRD Global Publishing. This is an open access article under the Creative Commons Attribution-

NonCommercial 4.0

Corresponding author's email address: rashid.sattar@iub.edu.pk

\section{Introduction}

The lower and middle income countries are different in their size of economies. The lower income countries are facing massive poverty and income inequality along with lack of technology and innovation adoptability which are major factors of international trade. The middle-income economies are essential for economic stability globally. These economies have a significant impact on international trade for rest of the world. On the other hand there is a wide wage gap between urban and rural wages in these economies(Chen, Alvarado, \& Hsu, 2018). The advantages of trade openness may not reach the 


\section{Review of Economics and Development Studies, Vol. 7 (2) 2021, 243-256}

rural poor, who are less aware and less movable than those living in urban areas. In Asia and SubSaharan Africa, there are some developing nations where income inequality increases due to trade openness. The trade openness benefits the people who live in urban areas as compared to rural ones (Ravallion, 2003). The skill of labor in developing economies plays an essential role in poverty reduction and income inequality and there exists a wide gap between the skill of labor in urban and rural areas. However, in some developing countries, poverty reduces due to free trade but income inequality remains the same. The income inequality in Asia and Africa is highest among all the regions of the World (Thomas, Wang, \& Fan, 2002).

Heckscher-Ohlin-Samuelsonmodel is based on the argument that abundant factors are intensively used in production due to its lower price that is determined by its abundance. After trade, there appears an increase in the price of abundant factors which has an income distribution effect (Robertson, 2000; Slaughter, 2000). It creates a link between trade openness and income inequality and poverty. There are a number of empirical evidences showing the encouraging effect of trade on poverty reduction (Pradhan and Mahesh, 2014; Onakoya et al. 2019).

The current pandemic also explains the association among trade openness, poverty and income inequality. There is an economic impact of COVID-19 through trade. The worldwide lockdown due to the corona virus results into dramatic change in international trade of all the economies globally. The pandemic shocks affected developing economies severely. The poverty increased due to lockdown in many economic zones in the World. The lockdown results into closure of many industries. In this condition the wages decrease and many people lose their jobs by which poverty increases. The trade was reduced and income inequality was increased (Buheji et al. 2020).

The association of trade openness, poverty, and income distribution received researcher's attention in this scenario. There is a lot of empirical evidences available showing the importance of the linkages of these variables. The evidences from the literature show that poverty and inequality are closely linked to each other(Guiga \& Rejeb, 2012). The literature found the ambiguity in findings regarding the linkages among this troika of macroeconomic indicators (Deyshappria, 2018). The developing economies are becoming more open, and inequality within and between developing economies has been increasing since long. The developing economies of Asia and sub-Saharan Africa are the particular cases. There has been significant discussion on the effects of trade openness, still the researchers are focusing on the connection among poverty, income distribution and trade openness(Jaravel, 2018).

The significant contribution of the current study is to examine the interrelationship among trade openness, poverty and income inequality in lower and middle-income economies of Asia and SubSaharan Africa. A comparative analysis of lower and middle-income economies in the perspective of trade openness, poverty and income inequality is still overlooked in the literature. The present research will fill this gap by comparing these two areas of developing economies.

\section{Literature Review}

An extensive literature exists on trade openness, poverty and income inequality. Most of it is concerned with any two variables of this triangle. Ravallion (2007) questioned the robust relationship between globalization and poverty. The study argued that under certain set of conditions the trade liberalization may reduce poverty but cross country analyses does not confirm that trade liberalization can reduce poverty. Khan and Bashir (2011) have analyzed the causal association of trade openness, poverty and income inequality with each other in India. The study revealed no effect of trade openness 


\section{Review of Economics and Development Studies, Vol. 7 (2) 2021, 243-256}

on poverty and poverty has no effect on trade openness, however, in the short run the income inequality is positively influenced by trade openness and in the long run it is negatively affected by trade openness.

Hussin and Saidin (2012) investigated the economic growth in four Asian countries: Malaysia, Thailand, Indonesia, and the Philippines. The Ordinary Least Square (OLS) technique was employed on the data set covering the time period from 1981 to 2008. The estimation explained that trade openness, foreign direct investment and gross fixed capital formation affect the GDP growth positively. These countries should devise the policies that encourage all these three socioeconomic indicators to accelerate the economic growth.

Elmawazini, Sharif, Manga, and Drucker (2013) empirically investigated the impact of trade and general globalization (combination of economic, social and political globalization) on income inequality in Commonwealth of Independent States (CIS) and South Europe. There were eight South Europe and CIS countries in the sample. The globalization was measured by KOF index of globalization which covers $37 \%$ of the economic dimension, $39 \%$ of the social size, and $24 \%$ of the political dimension. The results of Least Square Dummy Variable (LSDV) were divided into two parts. The first part showed that economic globalization widens inequality. The second part also showed the same type of impact of general globalization on income inequality.

Le Goff and Singh (2013) examined the issue of the trade and poverty in Africa. They found that open economies performed better than closed economies, especially concerning poverty elimination. The trade is sufficient for poverty reduction but it must be associated with other policies such as financial sector development, education, and governance. Santoss-Pauliuo (2015) also found that increase in export share contributes to poverty reduction.

Pradhan and Mahesh (2014) analyzed the role of trade openness in reducing poverty in developing countries. The results of Two stages Least Square (2SLS) model explained that poverty in the sample of 25 developing economies is negatively associated with total trade, i.e. sum of all kinds of imports and exports, along with separately only imports and exports. The merchandise trade has also shown negative effect on poverty.

Oh and Lee (2017) attempted to see how the poverty reduction in influenced by trade openness in regional perspective of 20 countries. The study concluded that export share in trade reduces national poverty and urban poverty in developing countries of Asia, and Central and South America but not the rural poverty. The import share in trade benefits the Central and South America in rural poverty reduction. Cain et al. (2010) have also argued that benefits of trade openness may differ for regions or sectors of the economies due to lack of capacity to absorb the advantages.

Mustafa, Rizov, and Kernohan (2017) investigated the bearing effect of trade openness and human development on GDP growth in a panel of 12 developing countries. The explanatory variables weretrade openness, human capital, foreign direct investment and GDP. The Three Stages Least Square (3SLS) methodology was used for estimation. The estimation explained that trade openness along with human capital substantially impact the economic growth in developing economies. The foreign direct investment also positively contributes in GDP growth rate.

Onakoya et al. (2019) estimated the impact of trade liberalization on poverty by employing Pooled OLS on the data set of twenty one African economies covering the time period of 2005-2014. 
Review of Economics and Development Studies, Vol. 7 (2) 2021, 243-256

They found that trade liberalization reduces poverty. Fauzel (2020) also estimated the role of trade in reducing poverty in Mauritius employing Error Correction Model on time series data for the years 19902017. The study concluded that in the long run the trade decreases poverty but in the short run it increases poverty. Moreover, GDP growth and education are the important factors for poverty alleviation.

Yameogo and Omojolaibi (2021) probed the impact of trade openness on economic growth and poverty in a sample of 40 sub-Saharan African economies. The study found that trade openness along with FDI and institutional quality increases economic growth. Furthermore, the trade openness and institutional quality reduce poverty. However, poverty does not respond to trade and growth shocks.

The literature has the gap of simultaneous analysis of trade openness, poverty and inequality in developing economies particularly focusing on lower and middle income economies.

\section{Theoretical Issues}

There are several channels through which trade influences poverty and income inequality. The income inequality exists in several economies since a long. These income inequalities remain existed in both developed and developing nations. One of the factors of this inequality is openness to international trade. The theories of international trade(Chen et al., 2018) demonstrate that trade increases wage inequality within the country and other countries. It is based onHeckscher-Ohlin-Samuelson theory which explains that factors of production cannot cross the border, so the factors can only move between industries within the countries. It results into change in income distribution. Through another channel income inequality is linked to international trade, i.e. the trade increase income inequality in importcompeting industries and reduce income inequality in export-producing industries(Ruffin, 2009).

As concerns the poverty there are a number of macroeconomic factors of poverty like unemployment (Calnitsky, 2018), low level of spending in education and training (Jagannathan \& Kocherlakota, 1996) and economic structure (Moller, Huber, Stephens, Bradley, \& Nielsen, 2003).

Poverty and inequality are often studied together because they are considered interrelated concepts. Issues of inequality focus on how resources are distributed in a society while poverty deals with either people can meet their basic needs. In the case of inequality, every person's status is compared with everyone else. According to endogenous growth theory (Dowrick \& Golley, 2004),trade openness may create dynamic gain by less expensive or high quality intermediate goods, enhancing the overall productivity of the economy. Through this effect trade contributes to reduce poverty. In turn, an increase in productivity also means high rate of taxation, high government investment, and better schooling, which are important determinants of poverty reduction. Hence, trade openness is a vital policy to reduce poverty (Dollar \& Kraay, 2004). According to Stolper Samuelsontheorem the trade increases the real income of unskilled labor due to its abundance in developing countries. Winters et al. (2004) concluded that trade liberalization is the most accessible tool of poverty reduction.

On the other hand, trade openness may harm the poor community of the country. The primary reason is that trade openness had to transform its labour into human capital (Rodrik, 2001). For low income countries, it is not possible to fully transform their labor into skilled and trained population which results into creation of poverty.

All schools of thought agree that trade remains impressive to increase growth which reduces poverty and income inequality. Different kinds of literature examined that trade is good for growth and 
to sustainability(Bhagwati \& Srinivasan, 2002; Dollar \& Kraay, 2004). Most of the developing countries opened their economies in the 1990s after performing much better economically, which benefited the poor. However, economic performance differs in developing economies depending on their resources and pattern of trade. Thus, poverty reduces to different extents in developing nations, so the magnitude of poverty reduction and income inequality differ in developing countries.

\section{Methodology}

The present study explained the interrelationship among trade openness, poverty, and income inequality. For the purpose three models have been devised. The functional form of the model is given as:

TRADE $=\mathrm{f}(\mathrm{POV}, \mathrm{GINI}, \mathrm{GDP}$, FDEV $)$

$\mathrm{POV}=\mathrm{f}(\mathrm{TRADE}, \mathrm{GINI}, \mathrm{GDP}, \mathrm{TAX})$

GINI $=\mathrm{f}(\mathrm{TRADE}, \mathrm{POV}, \mathrm{GDP}, \mathrm{HDEV})$

The operational definitions of the variables are given in Table 1.

Table 1: Operational Definitions of the Variables

\begin{tabular}{|c|c|}
\hline Variable name & Definitions and Sources \\
\hline $\begin{array}{l}\text { TRADE } \\
\text { (Trade openness) }\end{array}$ & It is the sum of exports and imports as a share of real GDP. \\
\hline $\begin{array}{l}\text { POV } \\
\text { (Poverty) }\end{array}$ & $\begin{array}{l}\text { The headcount ratio measures poverty. Headcount ratio at } \$ 1.90 \text { a day is } \\
\text { the percentage of the population living on less than } \$ 1.90 \text { a day. }\end{array}$ \\
\hline $\begin{array}{l}\text { GINI } \\
\text { (Income inequality) }\end{array}$ & $\begin{array}{l}\text { Gini-index measures the extent of income inequality. A Gini index of o } \\
\text { represents perfect equality, while an index of } 100 \text { implies perfect } \\
\text { inequality. }\end{array}$ \\
\hline $\begin{array}{l}\text { FDEV } \\
\text { (Financial } \\
\text { Development) }\end{array}$ & $\begin{array}{l}\text { Financial development is measured by credit to private sector ratio to total } \\
\text { credit. Domestic credit provided by the financial sector includes all credit } \\
\text { to various sectors on a gross basis, except for credit to the central } \\
\text { government, which is net. }\end{array}$ \\
\hline $\begin{array}{l}\text { GDP } \\
\text { (GDP growth rate) }\end{array}$ & The annual percentage growth rate of GDP. \\
\hline $\begin{array}{l}\text { TAX } \\
\text { (Tax revenue) }\end{array}$ & $\begin{array}{l}\text { Tax revenue refers to compulsory transfers to the central government for } \\
\text { public purposes. It is measured by tax to GDP ratio. }\end{array}$ \\
\hline $\begin{array}{l}\text { HDEV } \\
\text { (Human Development) }\end{array}$ & $\begin{array}{l}\text { Human development peroxide by Total enrollment in secondary education, } \\
\text { regardless of age, expressed as a percentage of the population. }\end{array}$ \\
\hline
\end{tabular}

\subsection{Panel Unit Root Test}

The most commonly used tests for Panel unit root are Levin, Lin, and Chu (LLC) test (Levin, Lin and Chu 2002), ImPesaran and Shin (IPS) test(Im, Pesaran, \& Shin, 2003), and augmented DickeyFuller (ADF) unit root test(Maddala \& Wu, 1999). These tests are employed to check the stationarity of data because sometimes data are stationary but sometimesit becomes stationary by taking its first difference. LLC is assumed Pooled Panel unit root test while heterogeneity is allowed by IPS. ADF is a non-parametric test. In the current study LLC, IPS and ADF tests are employed to check the stationarity. 


\subsection{Panel Cointegration Test}

If the variables under analysis in unit root tests are in order of integration one I(1) in the unit root tests, it allows to move forward to Panel Cointegration, representing a long-run equilibrium relationship among the variables. To estimate the cointegration, Kao Residual Cointegration test and Fisher Johnson Panel cointegration test are used. The base of this test is residuals of a dynamic model. It is suitable in the presence of cross-sectional dependency. The null hypothesis in this case may be nocointegration and its alternative hypothesis may be is cointegration. If cointegration exists, we can move towards Dynamic Ordinary Least Square (DOLS) and Fully Modified Ordinary Least Square (FMOLS). When cointegration in variables is confirmed, we estimate the coefficient of long-run magnitude.

It is essential to consider endogeneity because without considering this issue, misleading results may be emerged. The issue can be resolved by using DOLS and FMOLS regression techniques.

To avoid the existence of autocorrelation among the variables the FMOLS and DOLS are suitable for calculatingthe coefficient. DOLS is a parametric and FMOLS is a non-parametric approach. These approaches have the advantagesto handle small data. The FMOLS gives us efficient and unbiased estimators. The present study employs DOLS and FMOLS.

The econometric form of the models given in Equations 1, 2 and 3 are given here.

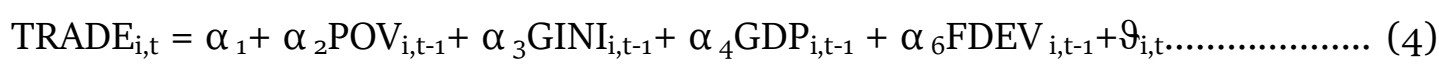

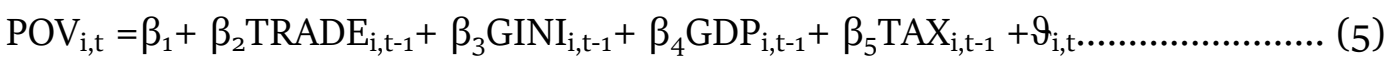

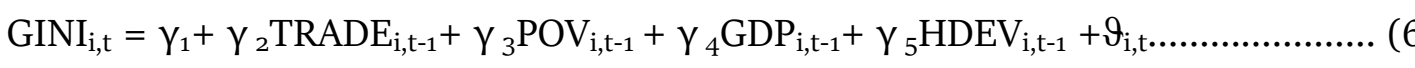

\subsection{Source of Data}

The sample of developing countries is comprised of 45 developing countries segregated into lower and middle income countries. All the countries in the sample are from two regions, i.e. Asia and Sub-Saharan Africa. There are 31 lower income and 14 middle income countries in the sample. The lower income countries under the World Bank classification are those having Gross National Income (GNI) per capita of \$1,026 to \$3,995 and middle income countries are those countries having the GNI per capita of $\$ 3,996$ to $\$ 12,375$. The data covering the time period of 1995-2019 is taken from World Development Indicators (World Bank 2019).

\section{Results and Discussion}

The results of panel unit root tests, the estimation results processed with panel cointegration using Kao and Fisher cointegration test, and the panel regression results using FMOLS and DOLS estimators are described in this section. The regression results showing the long run relationship among the principal variables are also discussed in this section.

\subsection{Results of Panel Unit Root Test}

The results of unit root test are expressed in Table 2 and 3.These results are estimated using LLC, IPS, and ADF-Fisher unit root test. The test values express that all the variables under analysis are non-stationary at first difference in both lower and middle income economies. So the series of variables are at I(1) in the panel of lower and middle income countries. Levine, Lin, and Chu (2002) demonstrated that it is necessary to check the unit root test for panel data in every section to avoid 
Review of Economics and Development Studies, Vol. 7 (2) 2021, 243-256

spurious regression. By rejecting the null hypothesis, we concluded that the reliability of each variable is fixed.

Table2: Unit Root Test for the Sample of Lower Income Countries

\begin{tabular}{|c|c|c|c|c|c|c|c|}
\hline \multirow{2}{*}{ Variables } & \multicolumn{2}{|c|}{ LLC } & \multicolumn{2}{c|}{ IPS } & \multicolumn{2}{c|}{ Results } \\
\cline { 2 - 7 } & level & $\begin{array}{c}\text { First } \\
\text { Diff. }\end{array}$ & level & $\begin{array}{l}\text { First } \\
\text { Diff. }\end{array}$ & level & First Diff. & \\
\hline TRADE & 0.94 & -15.3 & 0.92 & $-15.7^{*}$ & 59.0 & $366.3^{*}$ & $\mathrm{I}(1)$ \\
\hline POV & 2.45 & $-15.2^{*}$ & 1.86 & -16.5 & 57.0 & $376.9^{*}$ & $\mathrm{I}(1)$ \\
\hline GINI & 0.06 & $-11.0^{*}$ & 2.29 & $-20.5^{*}$ & 70.63 & $504.2^{*}$ & $\mathrm{I}(1)$ \\
\hline FDEV & 6.37 & $-12.1^{*}$ & 4.61 & $-12.8^{*}$ & 68.8 & $292.0^{*}$ & $\mathrm{I}(1)$ \\
\hline GDP & 6.72 & $-29.1^{*}$ & 1.92 & $-28.0^{*}$ & 44.90 & $616.8^{*}$ & $\mathrm{I}(1)$ \\
\hline TAX & 2.11 & -12.1 & 0.90 & $-15.0^{*}$ & 72.35 & $345.6^{*}$ & $\mathrm{I}(1)$ \\
\hline HDEV & 1.25 & $-14.3^{*}$ & 1.63 & $18.2^{*}$ & 88.23 & $273.2^{*}$ & $\mathrm{I}(1)$ \\
\hline
\end{tabular}

Note: ${ }^{* *},{ }^{* *}$ and $*$ represent significance at $1 \%, 5 \%$ and $10 \%$ levels respectively

Table 3: Unit Root Test for the Sample of Middle Income Countries

\begin{tabular}{|c|c|c|c|c|c|c|c|}
\hline \multirow{2}{*}{ Variables } & \multicolumn{2}{|c|}{ LLC } & \multicolumn{2}{c|}{ IPS } & \multicolumn{2}{c|}{ ADF } & \multirow{2}{*}{ Result } \\
\cline { 2 - 7 } & level & First Diff. & level & $\begin{array}{l}\text { First } \\
\text { Diff. }\end{array}$ & level & First Diff. & \\
\hline TRADE & 0.64 & $-8.80^{*}$ & 1.47 & $-9.75^{*}$ & 22.60 & $143.2^{*}$ & $\mathrm{I}(1)$ \\
\hline POV & -0.19 & $-10.1^{*}$ & -0.19 & $-0.62^{*}$ & 35.36 & $173.5^{*}$ & $\mathrm{I}(1)$ \\
\hline GINI & -0.31 & $-8.17^{*}$ & 0.11 & $-13.4^{*}$ & 531.5 & $198.2^{*}$ & $\mathrm{I}(1)$ \\
\hline FDEV & 3.23 & $-9.33^{*}$ & 3.70 & $-9.51^{*}$ & 12.40 & $141.9^{*}$ & $\mathrm{I}(1)$ \\
\hline GDP & 2.54 & $-16.3^{*}$ & -1.33 & $-15.8^{*}$ & 34.97 & $243.6^{*}$ & $\mathrm{I}(1)$ \\
\hline TAX & 2.83 & $-9.70^{*}$ & 2.66 & $-10.9^{*}$ & 15.27 & $164.5^{*}$ & $\mathrm{I}(1)$ \\
\hline HDEV & 3.21 & $-12.3^{*}$ & -0.24 & $-11.2^{*}$ & 30.27 & $223.0^{*}$ & $\mathrm{I}(1)$ \\
\hline
\end{tabular}

Note: ${ }^{* *},{ }^{* *}$ and $*$ represent significance at $1 \%, 5 \%$ and $10 \%$ levels respectively.

\subsection{Results of Panel Cointegration Test}

The variables are in order of integration one, now we estimate the cointegration relationship for the lowerand middleincome countries.For the purpose Kao panel cointegration test and Johnson Fisher cointegration test are applied on Equations 1, 2, and 3 representing the models for trade openness, poverty and income inequality respectively. The results of Kao residual cointegration test and Johanson Fisher panel cointegration test for both lower and middle income countries for Model 1 are shown in Tables 4 and 5 respectively. The results of same tests for Model 2 and 3 are given in Table 5, 6 and 7, 8 respectively.

Table 4: Kao Residual Cointegration Test for Model 1 (Trade openness)

\begin{tabular}{|c|c|c|c|c|}
\hline \multicolumn{2}{|c|}{ Lower Income Countries } & \multicolumn{2}{c|}{ Middle Income Countries } \\
\hline \multirow{2}{*}{ ADF } & t-Statistic & Prob. & t-Statistic & Prob. \\
\cline { 2 - 5 } & 1.872 & 0.030 & 5.297 & \multicolumn{2}{c|}{51.919} \\
\hline Residual variance & \multicolumn{2}{|c|}{79.138} & \multicolumn{2}{c|}{45.848} \\
\hline HAC variance & \multicolumn{2}{|c|}{68.851} & \multicolumn{2}{c|}{} \\
\hline
\end{tabular}


Review of Economics and Development Studies, Vol. 7 (2) 2021, 243-256

Table 5: Johansen Fisher Panel Cointegration Test for Model 1 (Trade openness)

\begin{tabular}{|c|c|c|c|c|c|c|c|c|c|}
\hline \multicolumn{5}{|c|}{ Lower Income Countries } & \multicolumn{5}{|c|}{ Middle-Income Countries } \\
\hline $\begin{array}{l}\text { Hypothesized } \\
\text { No. of CE(s) }\end{array}$ & $\begin{array}{c}\text { Fisher } \\
\text { Stat. } \\
\text { (from } \\
\text { trace } \\
\text { test) }\end{array}$ & Prob. & $\begin{array}{l}\text { Fisher } \\
\text { Stat.* } \\
\text { (from } \\
\text { max- } \\
\text { Eigen } \\
\text { test) }\end{array}$ & Prob. & $\begin{array}{l}\text { Hypothesized } \\
\text { No. of CE(s) }\end{array}$ & $\begin{array}{c}\text { Fisher } \\
\text { Stat. } \\
\text { (from } \\
\text { trace } \\
\text { test) }\end{array}$ & Prob. & $\begin{array}{l}\text { Fisher } \\
\text { Stat. } \\
\text { (from } \\
\text { max- } \\
\text { Eigen } \\
\text { test) }\end{array}$ & Prob. \\
\hline None & 874.7 & 0.00 & 600.2 & 0.00 & None & 240.9 & 0.00 & 240.9 & 0.00 \\
\hline At most 1 & 413.1 & 0.00 & 252.9 & 0.00 & At most 1 & 498.1 & 0.00 & 392.2 & 0.00 \\
\hline At most 2 & $219 \cdot 3$ & 0.00 & 165.6 & 0.00 & At most 2 & 303.2 & 0.00 & 243.8 & 0.00 \\
\hline At most 3 & $107 \cdot 3$ & 0.00 & $113 \cdot 3$ & 0.00 & At most 3 & 172.3 & 0.00 & 167.6 & 0.00 \\
\hline At most 4 & 45.28 & 0.94 & 45.28 & 0.94 & At most 4 & 47.03 & 0.01 & 47.03 & 0.01 \\
\hline
\end{tabular}

Table 6: Kao Residual Cointegration Test for Model 2 (Poverty)

\begin{tabular}{|c|c|c|c|c|}
\hline \multicolumn{2}{|c|}{ Lower Income Countries } & \multicolumn{2}{c|}{ Middle Income Countries } \\
\hline \multirow{2}{*}{ ADF } & t-Statistic & Prob. & t-Statistic & Prob. \\
\cline { 2 - 5 } & 3.529 & 0.000 & -1.625 & 0.051 \\
\hline Residual variance & \multicolumn{2}{|c|}{23.52} & \multicolumn{2}{c|}{6.205} \\
\hline HAC variance & \multicolumn{2}{|c|}{30.77} & \multicolumn{2}{c|}{} \\
\hline
\end{tabular}

Table 7: Johansen Fisher Panel Cointegration Test for Model 2 (Poverty)

\begin{tabular}{|c|c|c|c|c|c|c|c|c|c|}
\hline \multicolumn{5}{|c|}{ Lower Income Countries } & \multicolumn{5}{|c|}{ Middle-Income Countries } \\
\hline $\begin{array}{l}\text { Hypothesized } \\
\text { No. of CE(s) }\end{array}$ & $\begin{array}{c}\text { Fisher } \\
\text { Stat. } \\
\text { (from } \\
\text { trace } \\
\text { test) }\end{array}$ & Prob. & $\begin{array}{l}\text { Fisher } \\
\text { Stat. } \\
\text { (from } \\
\text { max- } \\
\text { Eigen } \\
\text { test) }\end{array}$ & Prob. & $\begin{array}{l}\text { Hypothesized } \\
\text { No. of CE(s) }\end{array}$ & $\begin{array}{c}\text { Fisher } \\
\text { Stat. } \\
\text { (from } \\
\text { trace } \\
\text { test) }\end{array}$ & Prob. & $\begin{array}{c}\text { Fisher } \\
\text { Stat. } \\
\text { (from } \\
\text { max- } \\
\text { Eigen } \\
\text { test) }\end{array}$ & Prob. \\
\hline None & 485.9 & 0.00 & 485.9 & 0.00 & None & 240.9 & 0.00 & 240.9 & 0.00 \\
\hline At most 1 & 1211. & 0.00 & 996.9 & 0.00 & At most 1 & 530.5 & 0.00 & 420.4 & 0.00 \\
\hline At most 2 & 632.6 & 0.00 & 507.7 & 0.00 & At most 2 & 250.9 & 0.00 & $194 \cdot 3$ & 0.00 \\
\hline At most 3 & 232.3 & 0.00 & 223.8 & 0.00 & At most 3 & 107.1 & 0.00 & 90.61 & 0.00 \\
\hline At most 4 & 86.8 & 0.02 & 86.8 & 0.02 & At most 4 & 61.68 & 0.01 & 61.68 & 0.00 \\
\hline
\end{tabular}

Table 8: Kao Residual Cointegration Test for Model 3 (Income Inequality)

\begin{tabular}{|c|c|c|c|c|}
\hline \multicolumn{2}{|c|}{ Lower Income Countries } & \multicolumn{2}{c|}{ Middle Income Countries } \\
\hline \multirow{2}{*}{ ADF } & t-Statistic & Prob. & t-Statistic & Prob. \\
\cline { 2 - 5 } & 5.798 & 0.000 & 1.573 & 0.05 \\
\hline Residual variance & \multicolumn{2}{|c|}{11.600} & \multicolumn{2}{c|}{14.642} \\
\hline HAC variance & \multicolumn{2}{|c|}{17.701} & \multicolumn{2}{|c|}{695} \\
\hline
\end{tabular}


Review of Economics and Development Studies, Vol. 7 (2) 2021, 243-256

Table 9: Johansen Fisher Panel Cointegration Test for Model 3 (Income Inequality)

\begin{tabular}{|c|c|c|c|c|c|c|c|c|c|}
\hline \multicolumn{5}{|c|}{ Lower Income Countries } & \multicolumn{5}{|c|}{ Middle Income Countries } \\
\hline $\begin{array}{l}\text { Hypothesized } \\
\text { No. of CE(s) }\end{array}$ & $\begin{array}{c}\text { Fisher } \\
\text { Stat.* } \\
\text { (from } \\
\text { trace } \\
\text { test) }\end{array}$ & Prob. & $\begin{array}{l}\text { Fisher } \\
\text { Stat.* } \\
\text { (from } \\
\text { max- } \\
\text { Eigen } \\
\text { test) }\end{array}$ & Prob. & $\begin{array}{l}\text { Hypothesized } \\
\text { No. of CE(s) }\end{array}$ & $\begin{array}{c}\text { Fisher } \\
\text { Stat. } \\
\text { (from } \\
\text { trace } \\
\text { test) }\end{array}$ & Prob. & $\begin{array}{c}\text { Fisher } \\
\text { Stat. } \\
\text { (from } \\
\text { max- } \\
\text { Eigen } \\
\text { test) }\end{array}$ & Prob. \\
\hline None & 485.9 & 0.00 & 485.9 & 0.00 & None & 206.8 & 0.00 & 240.9 & 0.00 \\
\hline At most 1 & 1249 & 0.00 & 996.9 & 0.00 & At most 1 & 542.3 & 0.00 & 392.2 & 0.00 \\
\hline At most 2 & 645.0 & 0.00 & 507.7 & 0.00 & At most 2 & 297.9 & 0.00 & 243.8 & 0.00 \\
\hline At most 3 & 308.1 & 0.00 & 223.8 & 0.00 & At most 3 & $95 \cdot 56$ & 0.00 & 167.6 & 0.00 \\
\hline At most 4 & 113.4 & 0.02 & 86.88 & 0.02 & At most 4 & 35.41 & 0.01 & 47.03 & 0.15 \\
\hline
\end{tabular}

Kao test and Johansen Fisher test confirm the presence of panel cointegration among the series of variables. The findings of Johansen Fisher have rank 4 for lower and middle-income countries, and the results confirm the presence of panel cointegration in all three equations. Trace test and Max-Eigen values are significant in the model. In the model Null Hypothesis is no cointegration which is rejected, and we accept the presence of cointegration in all the three models.

\subsection{Results of Panel Cointegration Regression}

The cointegration is confirmed for all the three models. In the next step coefficients are calculated.The results of FMOLS“Fully Modified Ordinary Least Square” and DOLS "Dynamic Ordinary Least Square” DOLS for Model 1 with dependent variable of trade openness for lower and middle income coutnres are reported in Table 10.

Table10: Cointegration Regression for Model 1 (Trade openness)

\begin{tabular}{|c|c|c|c|c|}
\hline \multicolumn{5}{|c|}{ Dependent variable: Trade openness } \\
\hline \multirow[t]{3}{*}{ Variables } & \multicolumn{2}{|c|}{ Lower Income Countries } & \multicolumn{2}{|c|}{ Middle Income Countries } \\
\hline & FMOLS & DOLS & FMOLS & DOLS \\
\hline & $\begin{array}{c}\text { Coefficients } \\
\text { (Prob) }\end{array}$ & $\begin{array}{c}\text { Coefficients } \\
\text { (Prob) }\end{array}$ & $\begin{array}{c}\text { Coefficients } \\
\text { (Prob) }\end{array}$ & $\begin{array}{c}\text { Coefficients } \\
\text { (Prob) }\end{array}$ \\
\hline POV & $\begin{array}{c}0.348 \\
(0.000)\end{array}$ & $\begin{array}{c}0.327 \\
(0.000)\end{array}$ & $\begin{array}{c}-1.091 \\
(0.003)\end{array}$ & $\begin{array}{c}-1.233 \\
(0.000)\end{array}$ \\
\hline GINI & $\begin{array}{l}-0.460 \\
(0.000)\end{array}$ & $\begin{array}{c}-0.756 \\
(0.000)\end{array}$ & $\begin{array}{c}1.388 \\
(0.000)\end{array}$ & $\begin{array}{c}1.282 \\
(0.000)\end{array}$ \\
\hline GDP & $\begin{array}{c}0.689 \\
(0.000)\end{array}$ & $\begin{array}{c}0.658 \\
(0.013)\end{array}$ & $\begin{array}{c}1.968 \\
(0.000)\end{array}$ & $\begin{array}{c}3.235 \\
(0.000)\end{array}$ \\
\hline FDEV & $\begin{array}{c}0.205 \\
(0.000) \\
\end{array}$ & $\begin{array}{c}0.214 \\
(0.000) \\
\end{array}$ & $\begin{array}{c}0.265 \\
(0.000)\end{array}$ & $\begin{array}{c}0.573 \\
(0.000)\end{array}$ \\
\hline No. of Observations & \multicolumn{2}{|c|}{775} & \multicolumn{2}{|c|}{330} \\
\hline No. of Groups & \multicolumn{2}{|c|}{31} & \multicolumn{2}{|c|}{14} \\
\hline
\end{tabular}

The results of FMOLS and DOLS in Table 10 explain that in lower income countries the poverty increases trade openness but in middle income countries it decreases trade openness. Similarly the 
Review of Economics and Development Studies, Vol. 7 (2) 2021, 243-256

income inequality has negative effect on trade openness in lower income countries but positive effect in middle income countries. It explains that poverty and income inequality have the role to influence trade openness but the direction of effect varies for income groups of the countries. In the literature such type of evidences are prevalent which have shown different effects of macroeconomic indicators for regions (Cain et al. 2010; Oh and Lee, 2017). Khan and Bashir (2011) have evidenced the negative impact of income inequality on trade openness in India.

However, the GDP growth rate increases trade openness in lower income as well as middleincome countries. The financial development has also shown encouraging effect on trade openness in both groups of countries. The results are supported by the literature (Arestis and Caner 20ogb). It explains that financial development plays an important role for trade openness irrespective of income groups of the economies.

The regression results for Model 2 with the dependent variable of poverty through FMOLS and DOLS regression are shown in Table 11.

Table 11: Cointegration Regression for Model 2 (Poverty)

\begin{tabular}{|c|c|c|c|c|}
\hline \multicolumn{5}{|c|}{ Dependent variable: Poverty } \\
\hline \multirow[t]{3}{*}{ Variables } & \multicolumn{2}{|c|}{ Lower Income Countries } & \multicolumn{2}{|c|}{ Middle Income Countries } \\
\hline & FMOLS & DOLS & FMOLS & DOLS \\
\hline & $\begin{array}{c}\text { Coefficients } \\
\text { (Prob) }\end{array}$ & $\begin{array}{c}\text { Coefficients } \\
\text { (Prob) }\end{array}$ & $\begin{array}{c}\text { Coefficients } \\
\text { (Prob) }\end{array}$ & $\begin{array}{c}\text { Coefficients } \\
\text { (Prob) }\end{array}$ \\
\hline TRADE & $\begin{array}{c}0.122 \\
(0.001)\end{array}$ & $\begin{array}{c}0.112 \\
(0.000)\end{array}$ & $\begin{array}{c}-0.058 \\
(0.188)\end{array}$ & $\begin{array}{c}-0.058 \\
(0.4037)\end{array}$ \\
\hline GINI & $\begin{array}{c}-0.081 \\
(0.280)\end{array}$ & $\begin{array}{l}-0.040 \\
(0.478)\end{array}$ & $\begin{array}{c}0.231 \\
(0.046)\end{array}$ & $\begin{array}{c}0.686 \\
(0.0031)\end{array}$ \\
\hline GDP & $\begin{array}{l}-0.108 \\
(0.185) \\
\end{array}$ & $\begin{array}{c}-0.188 \\
(0.002) \\
\end{array}$ & $\begin{array}{c}0.254 \\
(0.045) \\
\end{array}$ & $\begin{array}{c}0.434 \\
(0.0891) \\
\end{array}$ \\
\hline TAX & $\begin{array}{l}-0.187 \\
(0.041)\end{array}$ & $\begin{array}{l}-0.064 \\
(0.169)\end{array}$ & $\begin{array}{l}-0.204 \\
(0.173)\end{array}$ & $\begin{array}{c}-0.061 \\
(0.8196)\end{array}$ \\
\hline No. of Observations & \multicolumn{2}{|c|}{775} & \multicolumn{2}{|c|}{330} \\
\hline No. of Groups & \multicolumn{2}{|c|}{31} & \multicolumn{2}{|c|}{14} \\
\hline
\end{tabular}

The results of Equation 2, where poverty is dependent variable demonstrate that trade openness increases poverty in lower income countries but for the middle income countries the results are not statistically significant regarding the impact of trade openness on poverty. The evidences of adverse impact of trade openness on poverty reduction found in the existing literature (Ayinde, 2013). Yusuf et al. (2013) have found no impact of trade openness on poverty (Khan and Bashir, 2011). It explains that poor are unable to have the benefits of trade liberalization. It negates the $\mathrm{H}-\mathrm{O}$ theorem which states that trade results into increase in wages of lower income households who are generally involved in unskilled labor. It results into decrease in poverty. The results of current study explain that in the lower income countries the trade openness has the pattern that trade is absorbing the highly skilled and technologically quipped labor force which benefits a limited cluster of the people and masses become unemployed or under-waged resulting into increase in poverty. So the trade related poverty reduction policies are recommended so that the households living below poverty can have the benefits of trade. 
Review of Economics and Development Studies, Vol. 7 (2) 2021, 243-256

On the other hand income inequality has shown statistically insignificant impact on poverty in lower income countries but positive impact on poverty in middle-income countries.

The GDP growth has shown negative effect on poverty (only in DOLS regression) in lower income countries. The results are according to general perception and theory but GDP growth has shown positive impact on poverty (in FMOLS and DOLS regression) in middle-income countries. It explains the growth is pro-poor in lower income countries but it has poverty increasing tendency in middle-income countries. It is also strange that tax revenue decreases poverty in lower income countries but only from FMOLS region.

The results of FMOLS and DOLS for Model 3 with dependent variable of income inequality captured by Gini-index are shown in Table 12.

Table 12: Cointegration Regression for Model 3 (Income Inequality)

\begin{tabular}{|c|c|c|c|c|}
\hline \multicolumn{5}{|c|}{ Dependent variable: Income inequality } \\
\hline \multirow[t]{3}{*}{ Variables } & \multicolumn{2}{|c|}{ Lower Income Countries } & \multicolumn{2}{|c|}{ Middle Income Countries } \\
\hline & FMOLS & DOLS & FMOLS & DOLS \\
\hline & $\begin{array}{c}\text { Coefficients } \\
\text { (Prob) }\end{array}$ & $\begin{array}{c}\text { Coefficients } \\
\text { (Prob) }\end{array}$ & $\begin{array}{c}\text { Coefficients } \\
\text { (Prob) }\end{array}$ & $\begin{array}{c}\text { Coefficients } \\
\text { (Prob) }\end{array}$ \\
\hline TRADE & $\begin{array}{c}0.174 \\
(0.000)\end{array}$ & $\begin{array}{c}0.080 \\
(0.059)\end{array}$ & $\begin{array}{c}0.267 \\
(0.000)\end{array}$ & $\begin{array}{c}0.265 \\
(0.000)\end{array}$ \\
\hline POV & $\begin{array}{c}0.312 \\
(0.000)\end{array}$ & $\begin{array}{c}0.459 \\
(0.000)\end{array}$ & $\begin{array}{c}0.562 \\
(0.000)\end{array}$ & $\begin{array}{c}0.915 \\
(0.001)\end{array}$ \\
\hline GDP & $\begin{array}{c}0.574 \\
(0.000)\end{array}$ & $\begin{array}{c}0.953 \\
(0.000)\end{array}$ & $\begin{array}{l}-0.305 \\
(0.000)\end{array}$ & $\begin{array}{c}-0.837 \\
(0.000)\end{array}$ \\
\hline HDEV & $\begin{array}{c}0.330 \\
(0.000)\end{array}$ & $\begin{array}{c}0.323 \\
(0.000)\end{array}$ & $\begin{array}{c}0.347 \\
(0.000)\end{array}$ & $\begin{array}{c}0.358 \\
(0.000)\end{array}$ \\
\hline $\begin{array}{c}\text { No. of } \\
\text { Observations }\end{array}$ & \multicolumn{2}{|c|}{775} & \multicolumn{2}{|c|}{330} \\
\hline No. of Groups & \multicolumn{2}{|c|}{31} & \multicolumn{2}{|c|}{14} \\
\hline
\end{tabular}

The results of Equation 3, where income inequality is a dependent variable express that trade openness and poverty increase income inequality in lower and middle income countries. It is supported by the existing literature. For instance, Trabelsi and Liouane (2013) found that in developing economies the trade liberalization increases income inequality. It is suggested to adopt the strong governance and good macroeconomic policies to have the benefits of trade openness.

The GDP growth rate has been found increasing impact on income inequality in lower income countries but it decreases income inequality in middle-income countries. It explains that the income groups of the countries matter for the impact of economic growth on income inequality. In the lower income countries the growth increases income inequality while in middle income countries it decreases income inequality. It subsequently supports the Kuznet theorem stating that initially the growth increases income inequality but at the later stage of development it decreases income inequality.

Human development captured by the secondary school enrolment has shown increasing effect on income inequality in both lower and middle income countries. It demonstrates that at the initial stage of development the human development measured by secondary school enrolment in developing 


\section{Review of Economics and Development Studies, Vol. 7 (2) 2021, 243-256}

economies increases income inequality.

\section{Conclusion and Policy Recommendations}

The study analyzed the relationship among trade openness, poverty and income inequality by employing the FMOLS and DOLS on panel data set of 31 low income and 14 middle income countries covering the time period of 1995-2019. It concludes that trade openness increases poverty in lower income countries but it increases income inequality in both lower and middle income countries. So the trade openness policies for these groups of economies need modification in framework for trade openness. Poverty in lower income countries is increasing trade openness but in middle income countries it is decreasing trade openness. Poverty is increasing income inequality in both groups of the countries. Finally the income inequality decreases trade openness in lower as well as middle income countries. Income inequality increases poverty in middle-income countries. It may be concluded that there is an evidence of discouraging effect of trade openness on poverty and income inequality. Poverty has severe implications for income inequality and income inequality has severe implications for poverty. So there is a need to tackle the problems of poverty and income inequality simultaneously.

\section{References}

Ayinde, T. O. (2013). Trade liberalization, growth, and poverty reduction in Nigeria. Journal of Economics and Sustainable Development, 4(18), 93-106.

Arestis, P., \& Caner, A. (20o9a). Capital account liberalization and poverty: how close is the link? Cambridge Journal of Economics, 34(2), 295-323.

Arestis, P., \& Caner, A. (2009b). Financial liberalization and the geography of poverty. Cambridge Journal of Regions, Economy and Society, 2(2), 229-244.

Bhagwati, J., \& Srinivasan, T. N. (2002). Trade and poverty in the poor countries. American Economic Review, 92(2), 180-183.

Buheji, M., da Costa Cunha, K., Beka, G., Mavric, B., de Souza, Y., da Costa Silva, S. S., . . Y Yein, T. C. (2020). The extent of covid-19 pandemic socio-economic impact on global poverty. a global integrative multidisciplinary review. American Journal of Economics, 10(4), 213-224.

Cain, J., Hasan, R., \& Mitra, D. (2012). Trade liberalization and poverty reduction: New evidence from indian states. India's reforms: How they produced inclusive growth, 91-185.

Calnitsky, D. (2018). Structural and individualistic theories of poverty. Sociology Compass, 12(12), e12640.

Chen, P.-C., Alvarado, V., \& Hsu, S.-C. (2018). Water energy nexus in city and hinterlands: Multiregional physical input-output analysis for Hong Kong and South China. Applied Energy, 225, 986-997.

Deyshappria, R. (2018). Globalization-poverty nexuses: Evidences from cross-country analysis. Empirical Economic Review, 1(1), 24-48.

Dollar, D., \& Kraay, A. (2004). Trade, growth, and poverty. The Economic Journal, 114(493), F22F49.

Dowrick, S., \& Golley, J. (2004). Trade openness and growth: who benefits? Oxford Review of Economic Policy, 20(1), 38-56.

Elmawazini, K., Sharif, A., Manga, P., \& Drucker, P. (2013). Trade globalization, financial globalization and inequality within south-east Europe and cis countries. The Journal of Developing Areas, 303-317.

Fauzel, S. (2020). Investigating the impact of trade on poverty reduction in a small island economy. Forum for Social Economics, 49(2),1-20. 
Review of Economics and Development Studies, Vol. 7 (2) 2021, 243-256

Guiga, H., \& Rejeb, J. B. (2012). Poverty, Growth, and Inequality in Developing Countries. International Journal of Economics and Financial Issues, 2(4), 470-479.

Hussin, F., \& Saidin, N. (2012). Economic growth in ASEAN-4 countries: a panel data analysis. International Journal of Economics and Finance.

Im, K. S., Pesaran, M. H., \& Shin, Y. (2003). Testing for unit roots in heterogeneous panels. Journal of econometrics, 115(1), 53-74.

Jagannathan, R., \& Kocherlakota, N. R. (1996). Why should older people invest less in stocks than younger people. Federal Reserve Bank of Minneapolis Quarterly Review, 20, 11-20.

Jaravel, X. (2018). The unequal gains from product innovations: Evidence from the us retail sector. The Quarterly Journal of Economics, 134(2), 715-783.

Khan, R. E. A. \& Bashir, N. (2011). Trade liberalization, poverty and inequality nexus: a case study of India.Asian Economic and Financial Review, 1(3),114-119.

Le Goff, M., \& Singh, R. J. (2013). Does trade reduce poverty? A view from Africa.Washignton DC: The World Bank.

Levin, A., Lin, C.-F., \& Chu, C.-S. J. (2002). Unit root tests in panel data: asymptotic and finitesample properties. Journal of Econometrics, 108(1), 1-24.

Maddala, G. S., \& Wu, S. (1999). A comparative study of unit root tests with panel data and a new simple test. Oxford Bulletin of Economics and Statistics, 61(S1), 631-652.

Moller, S., Huber, E., Stephens, J. D., Bradley, D., \& Nielsen, F. (2003). Determinants of relative poverty in advanced capitalist democracies. American Sociological Review, 22-51.

Murshed, S. M. (2004). Globalization and South Asia: A Perspective. South Asia Economic Journal, $5(2), 311-326$.

Mustafa, G., Rizov, M., \& Kernohan, D. (2017). Growth, human development, and trade: The Asian experience. Economic Modelling, 61, 93-101.

Oh, S.\& Lee, S. H.(2017). Does trade contribute to poverty reduction? If it does, where the benefit goes to?, 2017 Annual Meeting, February 4-7, 2017, Mobile, Alabama 252849, Southern Agricultural Economics Association.

Onakoya, A., Johnson, B., \& Ogundajo, G. (2019). Poverty and trade liberalization: empirical evidence from 21 African countries. Economic Research-Ekonomska Istra zivanja, 32(1), $635-656$.

Pradhan, B. K., \& Mahesh, M. (2014). Impact of trade openness on poverty: A panel data analysis of a set of developing countries. Economics Bulletin, 34(4), 2208-2219.

Ravallion, M. (2003). The debate on globalization, poverty and inequality: why measurement matters. International Affairs, 79(4), 739-753.

Ravallion M (2007). Looking beyond averages in trade and poverty debate. In: Nissanke M and Thorbecke E, eds., The impact of globalization on the world's poor. Palgrave McMillan, UNU-WIDER Studies in DevelopmentEconomic and Policy.

Robertson, R. (2000). Trade liberalisation and wage inequality: lessons from the Mexican experience. World Economy, 23(6), 827-849.

Rodrik, D. (2001). Trading in illusions. Foreign PolicyNo.(123), 55-62.

Ruffin, R. J. (2009). Globalization and income inequality. Trade and Development Review, 2(2), 56-69

Slaughter, M. J. (2000). What are the results of product-price studies and what can we learn from their differences? The impact of international trade on wages (pp. 129-169): University of Chicago Press.

Santos-Paulino, A. \& Thornquist D. (2015). Estimating the impact of trade specialization and trade policy on poverty in developing countries, UNCTAD

Thomas, V., Wang, Y., \& Fan, X. (2002). A new dataset on inequality in education: Gini and Theil 
indices of schooling for 140 countries, 1960-2000. Washignton DC: World Bank.

Trabelsi, M. A., \& Liouane, N. (2013). Trade liberalization and fight against poverty. International Journal of Economics and Financial Issues, 3(2), 370-375.

Winters, A. L., McCulloch, N. \& McKay, A. (2004). Trade liberalization and poverty: evidence so far.Journal of Economic Literature, 42, 72-115.

World Bank (2019).World Development Indicators 2019. Available at https://data.worldbank.org/datacatalog/world-development-indicators Accessed on January 10, 2019.

Yameogo, C. E. W. \&Omojolaibi, J. A. (2021). Tradeliberalisation, economic growth and poverty level in sub-Saharan Africa (SSA). Economic Research-Ekonomska Istraživanja, 34(1), 754774.

Yusuf, M., Malarvizhi, C. A., \& Khin, A. A. (2013). Trade liberalization, economic growth and poverty reduction in Nigeria. International Journal of Business and Management, 8(12), 4247. 